\title{
National Interests of The Russian Federation in the Agricultural Sector: Features of the Integration of Environmental Factors in the World Pandemic and Their Reflection in the New Doctrine of Food Security
}

\author{
Liana Barashyan ${ }^{1, *}$ and Diana Kishka ${ }^{1}$ \\ ${ }^{1}$ Institute of Service and Entrepreneurship (Branch) of the Don State Technical University in Shakhty, \\ 110 Shevchenko str., Shakhty town, 346500 Rostov region, Russia
}

\begin{abstract}
The article is devoted to the study of the situation of the agroindustrial complex in an emergency situation related to the coronavirus pandemic. It is clear that in the present realities, against the background of the unstable conditions created by the systematic change of external factors, a competent organization of food security has become especially important. Thus, in the context of an unstable situation, the State has given priority to ensuring adequate food security, without which it was almost impossible to solve any of the tasks facing the State, both at the regional and federal levels. It was her condition that predetermined not only the economic development of the constituent entities of the Russian Federation, but also the habitat of a particular person. However, despite the projected positive trends, the State should envisage problems associated with a significant violation of economic policies. That is why the work presents an exceptional set of measures aimed at ensuring the food security of the population of Russia in the context of the global confrontation against the pandemic.
\end{abstract}

\section{Introduction}

COVID-19 poses new challenges worldwide, including for the agricultural sector. Currently, the outbreak of COVID-19 is spreading rapidly in different countries and covers most people around the world. COVID-19 Has serious and tragic consequences for human health due to high rates of proliferation and potentially fatal consequences. Scientists of the entire world community have focused their activities on combating the spread of the new virus and overcoming the consequences of the pandemic. [1] COVID-19 has a detrimental effect not only on human health, but also on the economy, both of the individual State and of the international community as a whole. The agricultural sector did not make an exception. Thus, scientists from various foreign countries are trying to assess the consequences of the pandemic and its impact on the agricultural sector, there is concern about food security and agricultural exports. The most vulnerable are generally underdeveloped countries. [3] The

* Corresponding author : barashyan.liana@yandex.ru 
pandemic has an impact on the reverse outflow of migrant workers employed in agriculture, the reduction of agricultural labour, which could jeopardize agricultural production and, therefore, the national food security of Asian countries. [4,5,6] Studies indicate that South Asian economies are threatened by a decline in agricultural supplies as a result of the pandemic. [7]. Studies conducted in Tehran note an improvement in food security during the initial period of the pandemic. COVID-19 Households have reduced the consumption of certain food groups during the pandemic COVID-19 compared to the pre-COVID-19 period, but it is noted that vulnerable groups in food-insecure countries, such as Iran, should receive food aid programmes to meet the needs of the population. [8] Research conducted in Nepal also shows the adverse impact of the pandemic on agriculture due to its growing dependence on imported resources (mainly seeds and fertilizers) from remote markets located in foreign countries. [9] Research conducted in Kenya and Uganda shows a significant decline in food security during the pandemic period. [10] In today's conditions, research is being conducted around the world to understand the impact of COVID-19 on the socio-economic impact on food production, agro-industrial development and food security. [11-15]

\section{Methodology}

The methodological basis of the study is general scientific methods - dialectical, formal logic, analysis and synthesis; private scientific methods - logical-legal, comparative-legal, systemstructural, document analysis, analysis of print and electronic publications, statistical methods.

\section{Results of the research}

The pandemic COVID-19 made significant changes in the production, economic, export activities of agro-industrial entities, which negatively affected the final financial results and well-being of organizations. At the state level, additional measures have been developed and are being taken to provide adequate food for the population, as well as the stable functioning of the industry. At the same time, members of the World Trade Organization should ensure, in such difficult circumstances, that a fair and market-oriented trading system is established in accordance with the provisions of the World Trade Organization Agreement on Agriculture by imposing restrictions on policies that distort agricultural production and trade. A serious obstacle was the destruction of a number of economic ties due to the isolation of cities and countries, the closure of national borders, and unstable supplies in the international trade system. In accordance with the expert assessments of international organizations, according to the optimistic scenario, the growth rate of the global economy over the year will decrease by $1.4 \%$. Its further development will depend on the effectiveness of the actions taken by Governments in relation to the national economy. However, the most probabilistic scenario will be the pessimistic scenario, which provides for several waves of epidemic, in which most of the world's population will get sick of COVID-19. In this situation, the world economy will recover by the end of 2022 , China - by the middle of 2021 , and the United States and the EU will return to the pre-crisis level only at the end of 2023.

Table 1. Industrial Safety Doctrine

\begin{tabular}{|c|c|c|c|}
\hline Product name & $\begin{array}{c}\text { Threshold } \\
\text { value 2010- } \\
\mathbf{2 0 2 0}\end{array}$ & Fact 2018 & $\begin{array}{c}\text { Threshold } \\
\text { value 2020+ }\end{array}$ \\
\hline grain & $95 \%$ & $99,4 \%$ & $95 \%$ \\
\hline potatoes & $95 \%$ & $94,9 \%$ & $95 \%$ \\
\hline
\end{tabular}




\begin{tabular}{|c|c|c|c|}
\hline sugar & $80 \%$ & $95,6 \%$ & $90 \%$ \\
\hline vegetable oil & $80 \%$ & $81,6 \%$ & $90 \%$ \\
\hline vegetables & - & $87,5 \%$ & $90 \%$ \\
\hline fruits and berries & - & $33,1 \%$ & $60 \%$ \\
\hline
\end{tabular}

Thus, summing up the above, it is advisable to note that the current state management system of the Russian agro-industrial complex needs modernization. The main areas of activity of the agro-industrial complex should be:

- improvement of technical and technological situation of Russian agriculture;

- increasing the profitability of agricultural producers;

- Increasing the social development of rural areas;

- Increasing employment of the population;

- Modernization of agricultural production, development of innovations;

- Increasing access of agricultural producers to the market, improving market infrastructure;

- Promotion of reproduction processes in the field of animal husbandry and crop production;

- Establishment of a system of public consultation and information centres in the regions;

- Adoption of measures to stimulate investment activity in the agro-industrial complex and increase the availability of credit resources and strengthen control over the targeted use of credit funds.

Furthermore, in this context, it is important to understand that, in the current circumstances, the imposition of import bans on imported food has contributed to the complete substitution of imported goods for the products of the domestic producer. These changes are undoubtedly a big impetus for the development of agriculture, the processing industry and ensuring the food security of the country, as well as the agro-industrial complex of Russia as a whole. Today, the current foreign policy situation requires the immediate activation of the activities of the Russian agro-industrial complex. However, it should not be forgotten that the analysis of trends and challenges for the agro-industrial complex is especially important in view of the large-scale problems that threaten the long-term food security of not only individual countries, but also humanity as a whole.

\section{Discussion of results}

Over the years, the agro-industrial complex of Russia has undergone serious changes after a change in the political course of our country, which occurred in the late 1990s of the XX century. Large state and cooperative farms operating in the mode of the planned economy have been replaced by enterprises of various forms of ownership, various numerical and quantitative formats, including farm and personal subsidiary farms, which operate on the principles of a free market economy. The agro-industrial complex, which directly includes the production and processing of agricultural products, is the main factor in ensuring the food security of the country, which in turn plays an important role in the overall system of security and self-sufficiency of the state. Given the fact that the economy of market relations is oriented to the demand of today and is influenced by changes in the political situation in the world, government regulation in the agro-industrial complex is of particular importance. The State, on the one hand, acts as a coordinating force and organizer of market relations between agricultural producers and their consumers, and on the other hand, it stimulates the areas and types of production that the State needs to ensure the long-term food security of the country.

In recent years, the general state of the agro-industrial complex, despite its dynamic development, is difficult to call stable. The agro-industrial complex of Russia with great difficulty overcame the transition from a planned management system to a market one. Only by the end of the 10s of the XX century, agricultural production adapted to change, having lost an impressive number of enterprises. At the moment, three main related problems of the 
agro-industrial complex could be distinguished: the political situation in the world (antiRussian sanctions), the lack of the possibility of obtaining profitable loans, the lack of qualified personnel resources.

Without dwelling on the analysis of the above-mentioned reasons, it can be noted that today the Russian agro-industrial complex has the potential to provide crop and livestock production throughout the country to ensure its food security. In addition, the state regulation of the agro-industrial complex in conditions of market relations certainly has its own characteristics, the main of which is that the forms of economic regulation are of a market nature, the purpose of which is to protect the domestic producer (development of economic mechanisms) from competition from foreign producers, protect the agricultural economy from monopolization, develop investment mechanisms, revive research potential, train personnel, solve social issues in rural areas. Obviously, only a state with its impressive potential can become a force organizing the development of the agro-industrial complex and a lever for the development of all the financial, tax, credit technical, educational and scientific capabilities of the country. According to official data, in Russia, 2020 billion rubles were allocated in the federal budget in 319.5 against 318.2 billion rubles in 2019, including 283.6 billion rubles for the state program for the development of agriculture, 35.9 billion rubles for the integrated development of rural areas.

The main areas of regulation of the agro-industrial complex can be considered:

- formation of conditions of market and foreign economic activity taking into account the sanctions regime, provision of preferential conditions of subsidies, financing and issuance of loans;

- ensuring the protection of Russian producers through the introduction of new customs duties and duties, and other restrictions on the import of imported products;

- development of the social and economic sphere in the towns, settlements, villages, villages and other places which are the centers of agricultural activity.

Every year, the Government of the Russian Federation establishes support programs for Russian agricultural producers aimed at supporting our domestic companies in a difficult political and economic situation. Billions of rubles from the federal budget are allocated to: - partial financing in the process of updating the technical fleet and technological equipment within the framework of the implementation of targeted agricultural support programs;

- Carrying out land reclamation activities;

- Granting preferential conditions for lending and subsidizing agricultural enterprises;

- formation of training programs for specialists and technical personnel of the agro-industrial complex and provision of appropriate training at the expense of federal and regional budgets.

In recent years, as can be seen from statistical reports, the agro-industrial complex of Russia has shown positive economic dynamics. At the same time, the issue of further development of the agro-industrial complex is especially acute, this is due to the increase in political and economic problems within the country and the increase in international tension.

Currently, in the conditions of modern research on the assessment of the state of the market economy, an ambiguous situation is noted, which determines the impossibility of implementing a number of social obligations of the state, affecting, first of all, the well-being of citizens. For many years, the question of providing adequate food at affordable prices has not lost its relevance. The general system of the country, which guarantees not only the selfsufficiency of the national need for food through domestic agriculture, but also measures to ensure food security, has for many years supported the economic activity of the citizen and his full participation in the public life of the country. However, it is important to understand that the peculiarity of the agri-food system provides a platform for integrating national economies into the global space, guarantees an increase in the investment attractiveness of local economic systems, and enhances their capitalization. Among other things, maintaining cooperation and strengthening relations with foreign States is an important aspect of the 
system. However, in the current conditions, it should be noted that the general change in the traditional climate in the country was initially facilitated by the emergence of numerous processes by foreign countries in the form of mutual sanctions, which made it necessary to adjust the export and import components of the domestic agricultural sector. This provision has undoubtedly had a great influence on strategic planning, as one of the key areas of the country's legal policy. It is clear that many significant aspects have been addressed in the current environment, which in turn necessitated changes in the regulatory framework for food security relations. The Food Security Doctrine of the Russian Federation, approved by Presidential Decree, predetermined the main priorities that form the ideological component in the agri-food sphere. In particular, in accordance with the criteria of the current state, the new Doctrine established rational decisions regarding the most important national interests.

However, in general, until today, the situation requires significant processing of existing

Regulations on food security. Obviously, the Doctrine only laid steady foundations for further legislative work aimed at developing a sectoral layer of norms with a clear indication of the competence of issues on the regulation of state agri-food relations.

Thus, it is important to note that it certainly took a considerable amount of time to adapt to the new realities, but in turn the realization of some stability was replaced by a new round, which overwhelmed important mechanisms of functioning and took priority position in almost all economic segments, both in Russia and around the world. The mainstreaming of new risks and the destruction of the sustainable growth paradigm were the result of a new global crisis caused by the spread of COVID-19. The transition to a problem actively discussed by the world public, it is noted that at the present stage the pandemic has become a significant challenge to the sustainable development of the agri-food system. So the first link in the pandemic was a significant reduction in the world's population. Obviously, in general, regardless of the time or type of epidemic, proliferation played a decisive role, as a result of which economic consequences could be assessed. However, mortality was not the only factor undermining the country's wealth dynamics. Undoubtedly, the state has faced equally important problems in the segment of the global food system, namely: disruption of supply chains, lack of labor due to restrictions on the movement of people, a change in the structure of demand for food due to a temporary decline in business activity of the population. All this from the point of view of modern logistics has had a serious impact on the process of normal life of the agro-industrial complex. Among other things, in the context of the rapid spread of coronavirus infection, the absence of goods and their rise in price, limiting the possibilities of socially unprotected words of the population in acquiring the necessary goods, as well as the quality of products consumed by the population, were of particular importance. A significant increase in risks in relations with foreign suppliers, one way or another, led to an increase in product prices, and therefore Russian companies were forced to increase prices for domestic products, which adversely affected demand. In general, on the basis of the above, the idea arises that the Russian legislator, suppressing some negative consequences, rapidly catalyzed the process leading to a imbalance in the already changing social mood of the country's population.

It is clear that in the present realities, against the background of the unstable conditions created by the systematic change of external factors, a competent food security organization was of particular importance. Thus, in the context of an unstable situation, the State has given priority to ensuring adequate food security, without which it was almost impossible to solve any of the tasks facing the State, both at the regional and federal levels. It was her condition that predetermined not only the economic development of the constituent entities of the Russian Federation, but also the habitat of a particular person. However, despite the projected positive trends, the State had to provide for problems related to a significant violation of economic policies. Since unprecedented food security cannot be achieved without taking into account the state of problems at the mega level. Thus, having analyzed measures to mitigate 
the impact of the pandemic and minimize negative consequences on the agro-industrial complex, it was advisable for the state to adhere to a rational component of protectionism, and for agro-producers to form a universal system of production and distribution of products that can adapt to the business environment. In addition, in this context, the Russian legislator had to take into account that any measures introduced to support the agro-industrial complex, first of all, have an impact on world trade.

Obviously, at the same time, while Russia was trying to overcome the crisis, in most countries of the world there was a decrease in business activity of public and private businesses, which, in turn, marked the adoption by the governments of various states of a set of economic and financial responses, including operational measures to provide the population with essential food and services, medical medicines and drugs.

According to experts of the International Monetary Fund, there was a huge decrease in consumer demand for products, due to two circumstances, namely, a decrease in citizens' incomes and fear of infection, which in turn showed increased uncertainty. According to official data published by the International Monetary Fund, according to the results of 2020, global GDP decreased by $3 \%$, and world trade by $13-32 \%$. The agri-food sector, being strategically important and vulnerable in the economic system of any state, constantly requires special attention, both at the national and global levels. In this context, it is important to note that for many decades the concept of "starvation of the population" has been steadily declining, but the trend of the last three years has predetermined the growth of starving people, who currently number about 820 million. Therefore, at the moment, the issue of eliminating the negative consequences of the pandemic by 2030 , for a successful return to the usual state, is a priority. According to the forecast of the Food and Agriculture Organization of the United Nations, global demand for agricultural products until 2021 will only increase, subject to growth, both in crop production and in livestock production. While urbanization, population growth, income and needs are identified as the main causes, a change in the epidemiological situation in the world is highlighted as additional. In this regard, the system of government regulation and support for rural producers requires expansion. At the same time, any decision taken by a government of a country must comply with international rules and its obligations, including within the framework of the World Trade Organization. So, by way of example, I would like to consider in more detail the consistent trends that are obvious today in some countries of the world.

As the main measures for the development of agricultural production in the Republic of Armenia, full subsidization of interest on loans for all investment projects, in particular drip irrigation systems, smart farms, cultivation of new fields and construction of new greenhouses, has been adopted. A mechanism has also been identified for changing the size of subsidies and the use of co-financing of agro-industrial complex programs. Thus, within the framework of the Eastern Partnership, the European Union will allocate agricultural assistance in the amount of 456 thousand euros.

The Republic of Kazakhstan used regional stabilization funds to purchase and ensure the availability of basic food products and their price stability during a state of emergency. A package of measures to support agricultural producers has also been introduced, including exemption from land tax, a reduction in VAT on some products, as well as a three-month delay in repaying loans. At the same time, to solve the food supply of the domestic market, borders are open for the accelerated import of six products into the country, quotas for the export of wheat grains and wheat flour have been established. To carry out spring field work this year, the Ministry of Agriculture of the Republic of Kazakhstan has increased the amount of funding by three times.

According to the results of 2019, the economic indicators of the Kyrgyz Republic reflected a certain growth in the agrarian economy. However, the situation under the influence of COVID-19 showed the food instability of the market and the financial instability 
of the economic entities of the agro-industrial complex. This was due to the fact that China, as one of the main trade and economic partners of Kyrgyzstan, has introduced quarantine measures in the country since the beginning of 2020 and, accordingly, has not ensured the implementation of its export agreements. Therefore, to maintain the situation in the domestic consumer market, a system of effective measures has been adopted in the country:

- The National Crisis Plan and Action Plan for Social Support and Food Security have been approved;

- 63 million soms were allocated from the state budget for the purchase of wheat flour and grain to replenish untouchable reserves, prices for wheat flour were fixed;

- the maximum level of wholesale and retail prices for a number of food products (wheat flour, potatoes);

- A semi-annual ban on the export of wheat, wheat flour, rice, vegetable oils and sugar has been introduced.

At the same time, the need to deepen mutual trade within the framework of the Eurasian Economic Union as an alternative direction to the "Chinese" segment has been determined. In particular, Kyrgyzstan turned to Kazakhstan for assistance and received food assistance in the amount of 5.4 million tons of wheat flour.

The Republic of Belarus is interested in the experience of other actual and potential trading partners. Studies show that the challenges faced by many countries around the world have had a negative impact on transport, storage, marketing, food financing and resource availability. According to the monitoring of the Food and Agriculture Organization of the United Nations, the subjects of the markets for fish and fish products, milk and dairy products, cereals and legumes suffered the most. Many countries in Europe and Central Asia have taken new measures to ensure sufficient domestic stocks and to avoid rising prices of staple foods. The most common were:

- Permission for food distribution (Albania, North Macedonia, Republic of Moldova);

- Provision of agricultural loans and financing (North Macedonia, Ukraine, Turkey);

- Administration of prices and market interventions (Belarus, Georgia, North Macedonia, Turkey);

- Promotion of marketing and development of e-commerce platforms (North Macedonia).

As for the Russian Federation, a fairly wide range of areas of support for the agroindustrial complex was used, among which it is necessary to highlight:

- Reduction to $15 \%$ of all insurance premiums for agricultural producers and deferral of payments;

- Provision of property tax subsidies, as well as the abolition of land tax for agricultural and processing organizations, catering and consumer services operating in rural areas;

- restructuring of tax debts (in the form of deferral, installments for the amount of principal debt and interest on taxes);

subsidizing interest rates on loans and investment projects received or refinanced after 1 March 2020;

- reduction of interest rates on commercial loans up to $5 \%$, and on preferential ones - up to $1 \%$.

Given that Russia is one of the world's leading exporters of grain, the country decided, after exporting grain declared under the quota, to suspend exports to non-member states of the Eurasian Economic Union. This event provided an opportunity to set stable prices for cereals and to meet the domestic needs of the country for grain and its processed products.

\section{Conclusions}

Overall, country policy analysis shows the use of a wide range of responses by World Trade Organization members to the pandemic. COVID-19 In this case, the organization's norms 
allow the introduction of a number of restrictions aimed at ensuring the health of citizens. The difficulty lies in the fact that the spread of diseases usually leads to: a reduction in the labor force (including seasonal workers and migrants), negatively affects the performance of field work during the year, affects the financial stability of producers, incomes of the population and food security. Despite the fact that the scale of the modern pandemic is not like any other crisis, I, on the basis of the approaches of specialists from the Food and Agriculture Organization of the United Nations, analyzed and systematized the most common in practice responses and recommended effective actions. Studies have shown that, in general, anti-crisis mechanisms in the agricultural sector should be aimed at eliminating the actual, rather than the perceived, imbalance between demand and supply for agricultural products and food. Avoiding trade-restricting measures can be no less effective policies than direct forms of support for producers and consumers. The creation of favourable legal, institutional, economic and financial conditions for the formation of transport and trade corridors can become the basis for stable food supplies and contribute to food security. Thus, the functioning of the World Trade Organization member economies in the face of a pandemic COVID-19 indicates their use of restrictive measures against the import or export of agricultural goods. The experience gained in foreign practice is of interest in the future for the development of an anti-crisis mechanism for the development of the Russian agroindustrial complex, taking into account international rules and requirements, as well as expanding the range of tools.

In general, the current state agrarian policy and the new response measures taken in Russia allow us to take into account the ongoing changes in the food market both inside and outside the country. And according to preliminary calculations, a state with good productive and economic potential in the agricultural sector, if necessary, can ensure an increase in food supplies to those countries that have faced the problem of food security in the pandemic.

\section{References}

1. L. Sperling, N. Louwaars, Orlando de Ponti, Melinda Smale, Dieudonne Baributsa, Jacob van Etten, Food Policy 97, $102000 \quad$ (2020) https://doi.org/10.1016/j.foodpol.2020.102000.

2. T. Perdana, D. Chaerani, Audi Luqmanul Hakim Achmad, Fernianda Rahayu Hermiatin, Heliyon, 6(10), e05128 (2020) https://doi.org/10.1016/j.heliyon.2020.e05128.

3. N. L. Ma, W. Peng, C. F. Soon, M. F. N. Hassim, S. Misbah, Z. Rahmat, W. T. L. Yong, C. Sonne, Environmental Research 193, $110405 \quad$ (2021) https://doi.org/10.1016/j.envres.2020.110405.

4. E. Workie, J. Mackolil, J. Nyika, S. Ramadas, Current Research in Environmental Sustainability 2, 100014 (2020) https://doi.org/10.1016/j.crsust.2020.100014.

5. Balwinder-Singh, P. B. Shirsath, M.L. Jat, A.J. McDonald, A. K. Srivastava, P. Craufurd, D.S. Rana, A.K. Singh, S.K. Chaudhari, P.C. Sharma, R. Singh, H.S. Jat, H.S. Sidhu, B. Gerard, Hans Braun, Agricultural Systems 185, 102954 (2020) https://doi.org/10.1016/j.agsy.2020.102954.

6. D. Boughton, J. Goeb, I. Lambrecht, D. Headey, H. Takeshima, K. Mahrt, I. Masias, S. Goudet, C. Ragasa, M. K. Maredia, B. Minten, X. Diao, Agricultural Systems 188, 103026 (2021) https://doi.org/10.1016/j.agsy.2020.103026.

7. G. Rasul, Environmental Challenges 2, 100027 https://doi.org/10.1016/j.envc.2021.100027. 
8. M. R. Pakravan-Charvadeh, F. Mohammadi-Nasrabadi, S. Gholamrezai, H. Vatanparast, C. Flora, A. Nabavi-Pelesaraei, Journal of Cleaner Production 281, 124537 (2021) https://doi.org/10.1016/j.jclepro.2020.124537.

9. J. Adhikari, J. Timsina, S. R. Khadka, Y. Ghale, H. Ojha, Agricultural Systems 186, 102990 (2021) https://doi.org/10.1016/j.agsy.2020.102990.

10. M. K. Kansiime, J.A. Tambo, I. Mugambi, M. Bundi, A. Kara, C. Owuor, World Development 137, 105199 (2021) https://doi.org/10.1016/j.worlddev.2020.105199.

11. A. Barman, R. Das, P. Kanti De, Current Research in Behavioral Sciences, 100017 (2021), https://doi.org/10.1016/j.crbeha.2021.100017.

12. M. Huss, M. Brander, M. Kassie, U. Ehlert, T. Bernauer, Global Food Security 28, 100468 (2021) https://doi.org/10.1016/j.gfs.2020.100468.

13. N. Elsahoryi, H. Al-Sayyed, M. Odeh, A. McGrattan, F. Hammad, Clinical Nutrition ESPEN 40, 171-178 (2020) https://doi.org/10.1016/j.clnesp.2020.09.026.

14. J. Ram Lamichhane, F.PF. Reay-Jones, Crop Protection 139, 105383 (2021) https://doi.org/10.1016/j.cropro.2020.105383.

15. S. O'Hara, E. C. Toussaint, Ecological Economics 180, 106859 (2021) https://doi.org/10.1016/j.ecolecon.2020.106859. 